ISSN: $1412-8837$

\title{
ANALISIS USAHA BUDIDAYA JAMUR TIRAM PUTIH (Pleurotus ostreatus) DI KECAMATAN CURUP TENGAH KABUPATEN REJANG LEBONG
}

\author{
BUSINESS ANALYSIS OF WHITE OYSTER MUSHROOM FARMING \\ IN CURUP TENGAH SUB-DISTRICT, REJANG LEBONG DISTRICT
}

\author{
Febri Nur Pramudya dan Indra Cahyadinata \\ Jurusan Sosial Ekonomi Pertanian Fakultas Pertanian Universitas Bengkulu
}

\begin{abstract}
The selection of oyster mushrooms as a commodity for business development in Bengkulu wooden mushroom cultivation because the cultivation of oyster mushrooms is relatively easier and faster than with other types of wood mushrooms. Rejang Lebong district is one of the areas in Bengkulu province of the white oyster mushroom cultivation. Business actors in the region of white oyster mushrooms contained in Rejang Lebong Curup Central District. Besides supported by the availability of raw materials in producing white oyster mushrooms such as sawdust, rice bran, lime, and the other as an additional element of media-making baglog, also supported by the availability of the white oyster mushroom market is big enough. The purpose of this study were: 1) Analyzing of income that be obtained from white oyster mushroom bussines of Curup Tengahsub discrict, rejang lebong discrict. 2)Analyzing of level profer or not profer white oyster mushroom bussines in midlle of curup sub discrict, rejang lebong discrict. 3)Analyzing the value- added that be obtained from the white oyster mushroom processing in curup sub discrict, rejang lebong discrict.

The results showed that the income earned in Curup Tengah subdistrict white oyster mushroom cultivation in the amount of $\mathrm{Rp}$. 3.901.470, -/Bulan. The magnitude of the efficiency of 1.88. Break even point dalah prices and production is $R p$ 13.703, - and $10,8 \mathrm{Kg}$. The amount of the added value obtained from the processing of white oyster mushrooms and a crispy nugget is equal to $33.49 \%$ or $R P 19.959,02$ and $53,77 \%$ or $R p$ $48.226,0253$.
\end{abstract}

Keywords: white oyster mushroom, production, revenue, cost, profit

\section{PENDAHULUAN}

Perkembangan pertanian di bidang pangan khususnya hortikultura pada saat ini ditujukan untuk lebih memantapkan swasembada pangan, 
meningkatkan pendapatan masyarakat, memperbaiki keadaan gizi melalui penganekaragaman jenis bahan makanan. Secara umum, Indonesia sebagai salah satu negara yang beriklim tropis mempunyai potensi yang cukup besar untuk mengembangkan produk-produk pertanian khususnya produk-produk pangan dimana didalamnya terdapat produk hortikultura yaitu buah-buahan dan sayuran.

Konsumsi hortikultura (buah-buahan dan sayuran) per kapita per tahun dari tahun 2004 ke 2007 cenderung meningkat. Tahun 2004 konsumsi hortikultura sebanyak $60,69 \mathrm{~kg} / \mathrm{kapita} / \mathrm{tahun}$, meningkat menjadi 66,86 $\mathrm{kg} / \mathrm{kapita} /$ tahun pada tahun 2005. Tahun 2006 terjadi penurunan konsumsi hortikultura sebesar 5 persen menjadi $57,72 \mathrm{~kg} / \mathrm{kapita} /$ tahun, namun meningkat kembali menjadi 59,52 kg/kapita/tahun pada tahun 2007.

Fungsi utama tanaman hortikultura bukan hanya sebagai bahan pangan tetapi juga terkait dengan kesehatan dan lingkungan. Fungsi tanaman hortikultura yaitu: fungsi penyediaan pangan, terutama dalam hal penyediaan vitamin, mineral, serat, energi, dan senyawa lain untuk pemenuhan gizi; fungsi ekonomi yaitu sumber pendapatan petani (pada umumnya komoditas hortikultura mempunyai nilai ekonomi yang tinggi), perdagangan, dan perindustrian; fungsi kesehatan, buah dan sayur dan terutama biofarmaka dapat digunakan untuk mencegah dan mengobati penyakit; fungsi sosial budaya, sebagai unsur keindahan/kenyamanan lingkungan, upacara-upacara, pariwisata, dan lain-lain.

Jamur adalah salah satu komoditas hortikultura yang dapat digunakan untuk pangan dan nutraceutical (makanan dan minuman untuk pencegahan dan pengobatan penyakit). Budidaya jamur memiliki prospek yang cukup cerah di Indonesia karena kondisi alam yang sangat mendukung, selain itu bahan baku untuk membuat substrat atau log tanam jamur cukup berlimpah. Indonesia berpotensi menjadi salah satu negara produsen jamur konsumsi (edible mushroom) karena memiliki berbagai jenis jamur yang bergizi tinggi dan dapat digunakan sebagai produk kesehatan. Hal ini dapat menjadi salah satu potensi untuk penerimaan negara.

Jamur konsumsi (edible mushroom) merupakan jamur yang mempunyai cita rasa dan nilai gizi yang tinggi sehingga dapat diterima oleh masyarakat. Di dunia dikenal 600 jenis jamur yang dapat dikonsumsi manusia. Namun, baru 200 jemis jamur yang dikonsumsi dab 35 jenis diantaranya telah dibudidayakan secara komersial. Jamur konsumsi tersebut diantaranya jamur tiram, jamur kuping dan jamur merang. Ketiga jenis jamur tersebut memang unggul dari segi cita rasa, tekstur, warna, nutrisi dan khasiat dibandingkan dengan jamur konsumsi lain pada umumnya. Jamur merang, jamur kuping, dan jamur tiram juga dapat dibudidayakan disebagian besar alam atau wilayah Indonesia yang bersuhu hangat. Proses budidaya jamur ini juga tidak terlalu rumit. Segmentasi pasarnya juga luas karena harganya yang sangat terjangkau (Pratiwi, 2010).

Pemilihan jamur tiram sebagai komoditi untuk usaha pengembangan budidaya jamur kayu di Bengkulu disebabkan karena budidaya jamur tiram ini relatif lebih mudah dan cepat dibandingkan dengan jenis jamur kayu lainnya. 
Hal ini cukup beralasan karena di Bengkulu usaha budidaya jamur kayu ini belum banyak dikenal. Budidaya jamur terdiri dari beberapa kegiatan mulai dari seleksi kultur jamur, pembuatan starter dan media tanam, penanaman, pemeliharaan jamur pada bedengan, pemanenan, penyimpanan dan pemasaran

Kabupaten Rejang Lebong merupakan salah satu wilayah di Provinsi Bengkulu yang membudidayakan jamur tiram putih. Pelaku usaha jamur tiram putih diwilayah Kabupaten Rejang Lebong terdapat di Kecamatan Curup Tengah. Selain didukung oleh ketersediaan bahan baku dalam memproduksi jamur tiram putih seperti serbuk gergaji, dedak, kapur, dan tambahan unsur lain sebagai media pembuatan baglog, juga didukung oleh ketersediaan pasar jamur tiram putih yang cukup besar. Permintaan jamur pada Kabupaten Rejang Lebong cukup tinggi dan produsen terbatas memenuhi permintaan yang ada.

Daerah Kabupaten Rejang Lebong di Kecamatan Curup Tengah terdapat 22 petani jamur tiram segar dan terdapat satu-satunya industri rumah tangga jamur tiram putih segar "Mekar Sari" yang memiliki pengolahan jamur tiram putih menjadi crispy dan nugget. Usaha tersebut telah berkembang selama 1 tahun. Pemasaran jamur tiram ini belum terlalu jauh, masih di sekitar wilayah Kabupaten Rejang Lebong karena keterbatasan modal. Banyaknya konsumen yang menggemari untuk mengkonsumsi jamur tiram putih membuat ketersediaan jamur tiram segar dan olahan menjadi terbatas. Oleh karena itu tujuan penelitian ini untuk mengetahui pendapatan, kelayakan usaha dan nilai tambah jamur tiram putih.

\section{METODE PENELITIAN}

\section{Metode Penentuan Lokasi dan Penetapan Responden}

Penentuan lokasi penelitian dilakukan secara sengaja (purposive) yakni di Kecamatan Curup Tengah Kabupaten Rejang Lebong. Hal ini didasarkan pada pertimbangan bahwa di Kecamatan Curup Tengah adalah satu-satunya Kecamatan yang mengolah jamur tiram di Kabupaten Rejang Lebong. Di Kecamatan Curup Tengah terdapat 22 populasi petani yang membudidayakan jamur putih.

Penelitian ini dilakukan terhadap para petani yang berada di Kecamatan curup Tengah yang merupakan petani jamur tiram. Dalm penelitian ini Responden petani jamur tiram putih ditetapkan secara purposive sejumlah 6 responden yang merupakan pelaku usaha jamur tiram putih yang aktif dan kontinu dalam memproduksi jamur tiram putih dalam rentang waktu 1 tahun terakhir.

Untuk usaha pengolahan jamur tiram putih menjadi crispy dan nugget di Kecamatan Curup Tengah terdapat Industri Rumah Tangga Mekar Sari. Pada penelitian responden ditetapkan purposive pada Industri Rumah Tangga Mekar Sari dengan pertimbangan bahwa Industri Rumah Tangga ini adalah satu- 
satunya Industri Rumah Tangga yang mengolah jamur tiram di Kecamatan Curup Tengah Kabupaten Rejang Lebong.

\section{Metode Analisis Data}

\section{Analisis Pendapatan}

Pendapatan usaha dari hasil pengolahan jamur tiram putih yang di dapat dari hasil penjualan produksi crispy dan nugget dikurangi dengan biaya yang dikeluarkan dalam proses produksi dalam waktu satu bulan produksi. Rumus yang digunakan (Soekartawi, 1995) yaitu:

$$
\begin{aligned}
& \mathrm{Pd}=\mathrm{TR}-\mathrm{TC} \\
& \mathrm{TR}=\sum_{i=1}^{n} Y . P y \\
& \mathrm{TC}=\mathrm{FC}+\mathrm{VC} \\
& \mathrm{VC}=\sum_{i=1}^{n} \text { Pxi. } \mathrm{Xi}
\end{aligned}
$$

dimana Pd adalah pendapatan usaha pengolahan jamur tiram (Rp/Bulan), TR adalah total penerimaan ( $\mathrm{Rp} /$ Bulan), TC adalah total biaya ( $\mathrm{Rp} /$ Bulan), Y adalah jamur tiram $(\mathrm{kg})$, Py adalah harga jamur tiram (Rp/kg), Y adalah Produksi usaha (kg/Bulan), Px adalah harga input ( $\mathrm{Rp})$, dan $\mathrm{X}$ adalah jumlah input.

\section{Analisis Efisiensi}

Untuk menganalisa efisiensi usaha digunakan metode $\mathrm{R} / \mathrm{C}$ ratio, dimana $\mathrm{R} / \mathrm{C}$ ratio merupakan perbandingan antara penerimaan dan biaya yang dikeluarkan (Soekartawi, 1995) yang dirumuskan sebagai berikut :

$\mathrm{R} / \mathrm{C}=\mathrm{TR} / \mathrm{TC}$

dimana kriteria yang digunakan adalah sebegai berikut :

1. Jika $\mathrm{R} / \mathrm{C}<1$, maka usaha jamur tiram putih yang diusahakan oleh rumah produksi tidak efisien ( tidak menguntungkan ).

2. Jika $\mathrm{R} / \mathrm{C}=1$, maka usaha jamur tiram putih yang diusahakan oleh industri rumah tangga mengalami pulang pokok (tidak untung dan tidak rugi).

3. Jika $\mathrm{R} / \mathrm{C}>1$, maka usaha jamur tiram putih yang diusahakan oleh industri rumah tangga efisien ( menguntungkan ). Usaha jamur tiram putih dikatakan layak jika $\mathrm{R} / \mathrm{C}$ ratio $>1$

\section{Analisis Break Event Point}

BEP dapat dihitung dalam bentuk unit atau harga tergantung untuk kebutuhan.

1. Atas dasar unit

$$
B E P_{\text {unit }} \frac{F C}{P-A V C}
$$

2. Atas dasar penjualan dalam rupiah

240 | Febri Nur Pramudya dan Indra Cahyadinata, Analisis Usaha Budidaya ... 


$$
B E P_{\text {rupiah }}=\frac{T C}{Q}
$$

dimana FC adalah Biaya Tetap, TC adalah total cost, $\mathrm{P}$ adalah Harga jual per unit, AVC adalah Biaya Variabel per unit, dan Q adalah Jumlah produksi

Menurut (Sofyan, 1998), BEP adalah dimana suatu perusahaan tidak mengalami laba atau tidak mengalami rugi atau istilah lain titik impas. Jika jumlah produksi melebihi titik impas, maka usaha tersebut dapat dikatakan layak.

\section{Analisis Nilai Tambah}

Untuk mengetahui besarnya nilai tambah yang diperoleh dari pengolahan jamur tiram putih menjadi crispy dan nugget metode perhitungan nilai tambah yang pernah digunakan Oleh Hayami (1989) dalam Khairiah (2002) dan Gusfarina (2007), dapat dilihat pada Tabel 1.

Tabel 1. Komponen untuk menghitung nilai tambah

\begin{tabular}{|c|c|c|}
\hline \multicolumn{2}{|r|}{ Output,Input, harga } & Nilai Tambah Pengolahan \\
\hline 1. & Hasil Produksi (output) (Kg/Hari) & A \\
\hline 2. & Bahan Baku (Input) (Kg/Hari) & B \\
\hline 3. & Tenaga Kerja (HOK) & $\mathrm{C}$ \\
\hline 4. & Faktor Konversi & $\mathrm{D}=\mathrm{A} / \mathrm{B}$ \\
\hline 5. & Koefisien Tenaga kerja $(\mathrm{HOK} / \mathrm{Kg} /$ Hari $)$ & $\mathrm{E}=\mathrm{C} / \mathrm{B}$ \\
\hline 6. & Koefisien Output (Rp/Kg/Hari) & $\mathrm{F}$ \\
\hline 7. & Upah Tenaga Kerja (Rp/Hok/Hari) & G \\
\hline \multicolumn{3}{|c|}{ Penerimaan Dan Keuntungan } \\
\hline 8. & Harga Bahan Baku (Rp/Kg/Hari) & $\mathrm{H}$ \\
\hline 9. & Biaya Input lainnya $(\mathrm{Rp} / \mathrm{Kg} /$ Hari) & I \\
\hline 10. & Nilai Output (Rp/Kg/Hari) & $\mathrm{J}=\mathrm{D} \times \mathrm{F}$ \\
\hline 11. & Nilai Tambah (RP/Kg) & $\mathrm{K}=\mathrm{J}-\mathrm{I}-\mathrm{H}$ \\
\hline 12. & Rasio Nilai Tambah (\%) & $\mathrm{L}=\mathrm{K} / \mathrm{J} \times 100 \%$ \\
\hline 13. & Pendapatan Tenaga Kerja (Rp/Kg/Hari) & $\mathrm{M}=\mathrm{E} \times \mathrm{G}$ \\
\hline 14. & Pangsa Tenaga Kerja (\%) & $\mathrm{N}=\mathrm{M} / \mathrm{K} X 100 \%$ \\
\hline 15. & Keuntungan (Rp/Kg/Hari) & $\mathrm{O}=\mathrm{K}-\mathrm{M}$ \\
\hline 16. & Tingkat Keuntungan (\%) & $\mathrm{P}=\mathrm{O} / \mathrm{K} \times 100 \%$ \\
\hline \multicolumn{3}{|c|}{ Balas jasa pemilik faktor-faktor produksi } \\
\hline 17. & Marjin $(\mathrm{Rp} / \mathrm{Kg})$ & $\mathrm{Q}=\mathrm{J}-\mathrm{H}$ \\
\hline 18. & Tenaga Kerja $(\%)$ & $\mathrm{R}=\mathrm{M} / \mathrm{Q} \times 100 \%$ \\
\hline 19. & Modal (sumbangan input lainnya) & $\mathrm{S}=\mathrm{I} / \mathrm{P} \times 100 \%$ \\
\hline
\end{tabular}

Sumber : Hayami 1989 dalam Khairiah (2002)dan Gusfarina (2007)

\section{HASIL DAN PEMBAHASAN}

\section{Karakteristik Petani Responden}

Karakteristik petani responden dalam penelitian ini dijelaskan yaitu nama responden, usia, tingkat pendidikan, pekerjaan utama, dan pengalaman berusahatani jamur tiram putih tersebut. Petani yang menjadi responden 
memiliki rentang usia antara 18-43 tahun,n petani yang paling tua berumur 43 tahun dan yang paling muda berumur 18 tahun, dengan rata-rata usia yaitu 34 tahun. Dalam usahatani, usia tersebut masuk dalam kategori usia produktif, dimana pada usia tersebut petani dapat melakukan kegiatan usahatani dengan maksimal karena tenaga dan semangat yang mereka miliki masih tinggi. Tidak hanya itu, keadaan umur tersebut juga menunjukkan bahwa para petani berada pada rentang usia yang masih produktif dimana akan berpengaruh terhadap pengambilan keputusan dan kemampuan fisik petani dalam melakukan kegiatan usaha tani. Untuk karakteristik responden dapat dilihat pada Tabel 2.

Tabel 2. Tabel Karakteristik Responden

\begin{tabular}{cccccc}
\hline No & $\begin{array}{c}\text { Nama } \\
\text { Petani }\end{array}$ & $\begin{array}{c}\text { Usia } \\
\text { (tahun) }\end{array}$ & $\begin{array}{c}\text { Tingkat } \\
\text { Pendidikan }\end{array}$ & $\begin{array}{c}\text { Pekerjaan } \\
\text { Utama }\end{array}$ & $\begin{array}{c}\text { Pengalaman } \\
\text { Usaha (tahun) }\end{array}$ \\
\hline 1 & Zainuri & 43 & SMA & Swasta & 3 \\
2 & Redho & 18 & SMA & Swasta & 1 \\
3 & Suyatno & 42 & SMK & Petani & 1.5 \\
4 & Soleh & 34 & SMP & Petani & 1.5 \\
5 & Sujak & 36 & SMP & Petani & 1.5 \\
6 & Artik & 36 & SMA & Petani & 1.5 \\
\hline \multicolumn{7}{c}{ Rata- rata } & 34.83 & SLTA & Petani & 1.67 \\
\hline
\end{tabular}

Sumber: Penelitian 24 Februari - 24 Maret 2012

Tabel 2 menunjukkan sebaran tingkat pendidikan formal petani responden dimana mayoritas petani responden memiliki tingkat pendidikan lulusan SMA sederajat atau kurang lebih sama dengan 12 tahun, pendidikan tersebut masuk dalam kategori pendidikan sedang.

\section{Biaya, Penerimaan, Dan Pendapatan}

\section{Biaya Produksi}

Faktor produksi merupakan hal yang sangat penting dalam usahatani jamur tiram putih. Faktor produksi yang dianalisis dalam penelitian ini meliputi biaya balog, bibit, biaya botol kaca, biaya kentang, biaya gula, biaya tepung jagung, biaya plastik, biaya ring balok, tenaga kerja, dan biaya bekatul. Keseluruhan biaya tersebut merupakan biaya variabel yang harus dikeluarkan pada setiap musim produksi jamur tiram. Untuk penggunaan biaya tetap yang dianalisis dalam penelitian ini meliputi : biaya abodemen listrik dan biaya listrik ditambah air yang digunakan, serta biaya penyusutan alat yang digunakan. jumlah rata-rata biaya variabel yang dikeluarkan oleh keenam responden/pengusaha jamur tiram yaitu sebesar Rp 3.826.072. Biaya tersebut meliputi biaya baglog, bibit, biaya botol kaca, kentang, biaya gula putih, biaya tepung jagung, biaya plastik, biaya ring balok, dan biaya bekatul serta biaya 
pembelian alat. Sedangkan jumlah biaya tetap rata-rata dari keenam responden berdasarkan Tabel 3, besarnya biaya tersebut yaitu sebesar Rp 75.397,00 biaya tersebut meliputi biaya penyusutan alat, biaya abodemen listrik dan air, serta biaya pemakaian listrik. Biaya-biaya tersebut tidak berpengaruh terhadap kenaikan produksi, sebaliknya biaya kenaikan biaya variabel akan mempengaruhi produksi.

\section{Penerimaan usahatani}

Berdasarkan hasil analisis menunjukkan bahwa penerimaan usaha budidaya jamur tiram di Kecamatan Curup Tengah diperoleh dari hasil kali antara produksi jamur tiram dengan harga jual yang berlaku di tingkat konsumen. Berikut dapat dilihat di Tabel 3 gambaran rata-rata penerimaan, harga dan produksi jamur tiram di Kecamatan Curup Tengah.

Tabel 3. Rata-rata penerimaan, produksi dan harga jual usahatani jamur tiram putih di Kecamatan Curup Tengah, per bulan

\begin{tabular}{crrrr}
\hline No & $\begin{array}{c}\text { Produksi } \\
(\mathrm{Kg})\end{array}$ & $\begin{array}{c}\text { Harga jual } \\
(\mathrm{Rp} / \mathrm{Kg})\end{array}$ & $\begin{array}{c}\text { Penerimaan (PxQ) } \\
(\mathrm{Rp} / \text { Bulan })\end{array}$ & $\begin{array}{c}\text { Persentase penjualan } \\
\text { jamur tiram segar }\end{array}$ \\
\hline 1 & 505,5 & 24000 & 12132000 & $28 \%$ \\
2 & 496 & 23000 & 11408000 & $26 \%$ \\
3 & 368 & 23000 & 8464000 & $19 \%$ \\
4 & 324 & 23000 & 7452000 & $17 \%$ \\
5 & 98 & 20000 & 1960000 & $5 \%$ \\
6 & 104 & 20000 & 2080000 & $5 \%$ \\
\hline Jumlah & 1895,50 & 133000 & 43496000 & $100 \%$ \\
Rerata & 315,92 & 22167 & 7249333 & \\
\hline
\end{tabular}

Sumber: Penelitian 24 Februari - 24 Maret 2012

Dari tabel di atas dapat dilihat bahwa rata-rata penerimaan per bulan dalam satu bulan pengamatan usahatani jamur tiram putih di Kecamatan Curup Tengah yaitu sebesar Rp. 7.249.333,-. Dengan rata-rata produksi per bulan yaitu sebanyak 315,92 kg dan dijual dengan tingkat harga rata-rata yaitu Rp. 22.167. Penerimaan ini merupakan penerimaan yang berasal dari produk jamur langsung jual atau biasa disebut jamur segar. Di Kecamatan Curup Tengah, umumnya para petani hanya menjual jamur dalam bentuk segar, hal tersebut dapat dilihat dari Tabel 3 yang menjelaskan bahwa lima dari enam petani yang menjadi responden dalam penelitian ini menjual jamur tiram dengan cara dijual langsung, atau di jual segar. Harga penjualan jamur tiram putih ini berbedabeda diakibatkan oleh faktor pemasaran. Ada yang langsung dijual ke konsumen ada juga yang menjualnya ke pasar langsung. Jika petani menjual langsung ke konsumen yang datang ke rumah pembudidaya maka harga jamur yang dijual petani tersebut rata-rata Rp 20.000,00/kg. Apabila dijual ke pasar 
maka harga jamur tersebut dapat terjadi tawar menawar yang membuat harga jamur menjadi mahal. Akan tetapi salah satu responden seperti Zainuri karena telah berusahatani berpengalaman lama, maka konsumen lebih sering membeli jamur dari tempat budidayanya karena jamur segar budidaya zainuri ini sudah banyak diketahui masyarakat.

\section{Pendapatan Usahatani}

Keberhasilan kegiatan usahatani dapat dilihat melalui analisis pendapatan usahatani. Pengeluaran total usahatani jamur tiram putih ini terdiri dari pengeluaran tetap dan pengeluaran variabel. Pendapatan adalah selisih antara penerimaan dengan biaya produksi. Menurut Hernanto (1989), analisis pendapatan pada umumnya digunakan untuk mengevaluasi kegiatan usaha pertanian dalam satu tahun, dengan tujuan untuk membantu perbaikan pengelolaan usahatani. Analisis pendapatan usahatanai bertujuan untuk mengetahui besarnya keuntungan yang diperoleh dari usaha yang dilakukan.

Dari hasil penelitian yang dilakukan pada petani jamur tiram putih di Kecamatan Curup Tengah didapatlah data untuk analisis pendapatan dengan menggunakan rumus untuk menghitung pendapatan. Untuk perhitungan jumlah dan rata TR dan pendapatan dapat dilihat pada Tabel 4.

Tabel 4. Rata-rata dan jumlah pendapatan usahatani jamur tiram di Kecamatan Curup Tengah.

\begin{tabular}{lc}
\hline \multicolumn{1}{c}{ Uraian } & Rata-rata (Rp/bulan) \\
\hline Penerimaan (TR) & $\operatorname{Rp~7.249.333,-~}$ \\
Total biaya (TC) & $\operatorname{Rp~3.901.470,-~}$ \\
Pendapatan (Pd) & $\operatorname{Rp} 3.347 .864,-$ \\
\hline
\end{tabular}

Sumber: Penelitian 24 Februari - 24 Maret 2012

Dari tabel di atas, dapat dilihat bahwa rata-rata pendapatan yaitu sebesar Rp 3.347.864 per bulan usahatani tersebut dijalankan. Pendapatan tersebut merupakan pengurangan dari penerimaan dengan total biaya rata-rata keseluruhan. Penerimaan keseluruhan dari usahatani jamur tiram putih di Kecamatan Curup Tengah yaitu sebesar Rp 7.249.333,- dengan total biaya yaitu sebesar Rp 3.901.470,--

Bila dilihat dari penelitian sebelumnya yang dilakukan oleh Balqis, 2010 di Samarinda yang melihat analisis usaha budidaya jamur tiram putih,hasil ratarata yang didapatkan dari 6 responden untuk penerimaan adalah sebesar Rp. 6.712.500,-. Untuk 6 responden Curup Tengah menghasilkan Rp 7.249.333,- bila dianalisis nilai yang dihasilkan Petani Curup Tengah lebih besar dibandingkan dengan Petani Samarinda dengan melihat jumlah responden yang lebih banyak di samarinda dari pada di Kecamatan Curup Tengah Kabupaten Rejang Lebong. Hal ini dikarenakan letak geografis Samarinda adalah dataran rendah, sedangkan Curup Tengah adalah dataran tinggi. Di dataran rendah seperti 
Samarinda yang memiliki suhu tinggi dan kelembaban rendah pula yang mengakibatkan budidaya jamur tiram putih lebih sulit dibandingkan dengan dataran tinggi hal ini karena dibutuhkan penyiraman yang terus menerus untuk meningkatkan kelembapan suhu. Sedangkan Curup Tengah lebih unggul untuk budidaya jamur tiram putih karena keadaan yang memiliki suhu rendah dan kelembapan tinggi sehingga para petani dapat meminimalisir penyemprotan. Di samping itu, produksi jamur tiram di Kecamatan Curup Tengah rendah dikarenakan, petani jamur tiram di Kecamatan Curup Tengah belum terlalu terampil dalam membudidayakan usahatani jamur tiram. Hal tersebut didukung data di lapangan, menurut Zainuri salah satu Petani "saya masih sering gagal dalam membudidayakan usahatani jamur tiram, sering baglog yang saya buat tidak tumbuh jamur". Hal tersebut menandakan masih perlunya pelatihan dan pendidikan baik formal dan informal dalam membudidayakan usahatani jamur tiram di Kecamatan Curup Tengah.

\section{Efisiensi Usahatani.}

Efisiensi usaha, digunakan metode RC ratio, merupakan perbandingan antara penerimaan dan biaya yang dikeluarkan adapun hasil dari perhitungan analisi efisiensi dari penelitian dapat dilihat pada Tabel 5.

Berdasarkan Tabel 5, rata-rata efisiensi usahatani jamur tiram di Kecamatan Curup Tengah yaitu sebesar 1,88. Nilai efisiensi tersebut menjelaskan bahwa usahatani jamur tiram di Kecamatan Curup Tengah menguntungkan. Efisiensi membandingkan antara penerimaan dengan total biaya yang dikeluarkan. Rata-rata total biaya (TC) usahatani jamur putih di Kecamatan Curup Tengah sebesar Rp 3.901.470,- dengan tingkat penerimaan sebesar Rp. 7.249.333,- Nilai 1,88 menginformasikan bahwa setiap Rp. 1 yang dikorbankan pengusaha jamur tiram akan dapat menghasilkan Rp. 1,88,-- Oleh sebab itu, usaha jamur tiram ini layak untuk diusahakan.

Tabel 5. Jumlah dan Rata-rata Tingkat Efisiensi (R/C) Pendapatan Petani Jamur Tiram di Kecamatan Curup Tengah.

\begin{tabular}{crcc}
\hline NO & PENERIMAAN (Rp) & TOTAL BIAYA (Rp) & EFISIENSI \\
\hline 1 & 12.132 .000 & 3.237 .848 & 3,75 \\
2 & 11.408 .000 & 8.483 .077 & 1,34 \\
3 & 8.464 .000 & 4.082 .954 & 2,07 \\
4 & 7.452 .000 & 4.066 .343 & 1,83 \\
5 & 1.960 .000 & 1.769 .298 & 1,11 \\
6 & 2.080 .000 & 1.769 .298 & 1,18 \\
\hline JUMLAH & 43.496 .000 & 23.408 .818 & 11,28 \\
RATA-RATA & 7.249 .333 & 3.901 .470 & 1,88 \\
\hline
\end{tabular}

Sumber: Penelitian 24 Februari - 24 Maret 2012 


\section{Break Even Point}

BEP atau titik impas adalah suatu kondisi dimana suatu usaha tidak mengalami kerugian ataupun memperoleh laba. Untuk dapat menentukan tingkat titik impas maka biaya yang dikeluarkan harus dapat dipisahkan menjadi biaya tetap dan biaya variabel, serta harga jual per unit tidak berubah selama periode yang dianalisis. Dalam penelitian ini dilakukan analisis terhadap masing-masing biaya break even point berdasarkan harga dan break even point berdasarkan produksi.

\section{Break Even Point Produksi}

Biaya tetap adalah biaya yang jumlah totalnya tetap, tidak berubah dalam range output tertentu, tetapi untuk setiap satuan produksi akan berubah-ubah sesuai dengan perubahan produksi. Biaya variabel adalah biaya yang jumlah totalnya akan naik turun sebanding dengan hasil produksi atau volume kegiatan, tetapi untuk setiap satuan produksi akan tetap. Analisis titik impas produksi usahatani jamur tiram putih di Kecamatan Curup Tengah disajikan pada Tabel 6.

Berdasarkan Tabel 6, titik impas produksi jamur tiram keseluruhan di Kecamatan Curup Tengah yaitu sebesar $64,8 \mathrm{~kg}$ dengan rata-rata nilai titik impas produksi sebesar $10,8 \mathrm{~kg}$ per pengusaha. Hal tersebut menunjukan bahwa pada usahatani jamur tiram di Kecamatan Curup Tengah, harus terjual rata-rata sebanyak $10,8 \mathrm{~kg}$ jamur tiram untuk mencapai titik impas atau keadaan seimbang dimana tidak terjadi kerugian atau mendapat keuntungan. Nilai BEP produksi menunjukan bahwa nilai tersebut merupakan nilai yang harus dicapai oleh petani untuk mencapai keadaan seimbang. Jumlah titik impas ini jauh dari rata - rata produksi yang dihasilkan yang mencapai $315,9 \mathrm{~kg}$. Atau dengan kata lain, pengusa jamur tiram hanya perlu memproduksi $37 \%$ dari pasitas produksi mereka saat ini untuk tidak mengalami kerugian ataupun tidak untung.

Tabel 6. Jumlah dan rata-rata tingkat Break Even Point produksi usaha jamur tiram di Kecamatan Curup Tengah.

\begin{tabular}{cccc}
\hline No & Output/hasil $(\mathrm{kg})$ & BEP Produksi(kg) & Persentase $\%$ \\
\hline 1 & 505,5 & 6,11 & 82,73 \\
2 & 496 & 13,7 & 36,2 \\
3 & 368 & 8,03 & 45,83 \\
4 & 324 & 7,58 & 42,74 \\
5 & 98 & 17,3 & 5,66 \\
6 & 84 & 12,09 & 6,95 \\
\hline Jumlah & 1895,5 & 64,8 & 220,12 \\
Rata-rata & 315,9 & 10,8 & 36,68 \\
\hline
\end{tabular}

Sumber: Penelitian 24 Februari - 24 Maret 2012

246 | Febri Nur Pramudya dan Indra Cahyadinata, Analisis Usaha Budidaya ... 


\section{Break Even Point Harga}

Titik impas berdasarkan harga merupakan tingkat dimana penjualan yang dilakukan oleh petani atau pelaku usahatani, dengan harga yang diterima oleh petani tersebut impas, petani tersebut tidak mengalami keuntungan dan kerugian. Rata-rata tingkat BEP beradasarkan harga dijelaskan oleh Tabel berikut ini.

Tabel 7. Rata-rata dan jumlah Break even point berdasarkan harga pada usahatani jamur tiram di Kecamatan Curup Tengah.

\begin{tabular}{cccc}
\hline No & Harga (000,-) (Rp) & BEP Harga (000,-) (Rp) & Persentase (\%) \\
\hline 1 & 24.000 & 6.405 & 3,75 \\
2 & 23.000 & 17.103 & 1,34 \\
3 & 23.000 & 11.095 & 2,07 \\
4 & 23.000 & 12.550 & 1,83 \\
5 & 20.000 & 18.054 & 1,11 \\
6 & 20.000 & 17.012 & 1,18 \\
\hline Jumlah & 133.000 & 82.220 & 11,28 \\
Rata-rata & 22.167 & 13.703 & 1,88 \\
\hline
\end{tabular}

Sumber: Penelitian 24 Februari - 24 Maret 2012

Berdasarkan Tabel 5.7, BEP harga yang didapat oleh peneliti yaitu sebesar Rp. 82.220,- dengan rata-rata BEP harga yang dikeluarkannya dalam 1 bulan yaitu sebesar Rp 13.703,-. BEP harga tersebut menjelaskan bahwa pengusaha atau petani jamur tiram harus menjual jamur tiram yang mereka hasilkan pada tingkat rata-rata harga yang telah ditentukan yaitu sebesar Rp. 13.703. Jika petani tersebut menjual jamur tiram dibawah harga rata-rata tersebut, maka petani tersebut akan mengalami kerugian dalam mengusahakan usahatani jamur tiram tersebut. Rata-rata kemampuan petani untuk mencapai harga keseimbangan rata-rata yaitu sebesar $1,88 \%$. Hal tersebut menunjukan bahwa harga jual jamur tiram putih yang diterima oleh petani jamur tiram putih di atas harga jual pada tingkat harga impas, sehingga dengan harga jual yang diterima tersebut, petani tersebut mendapat keuntungan dari usahatani jamur tiram yang mereka lakukan.

\section{Nilai Tambah Olahan Jamur Tiram Putih}

Dalam penelitian ini selain melihat analisis pendapatan petani dari penjualan jamur tiram putih segar, selain itu penelitian ini juga menlihat analisis nilai tambah yang dihasilkan dari salah satu U.D yang dikembangkan oleh salah satu petani yaitu U.D Mekar Sari oleh Bapak Zainuri. Dalam menganalisis nilai tambah pada penelitian ini, peneliti melihat adanya kegiatan pengolahan jamur tiram putih segar menjadi produk olahan yang menguntungkan yaitu crispy jamur dan nugget jamur. Dalam pengolahan produk tersebut digunakan pula 
berbagai macam nilai biaya tambahan seperti biaya penolong produksi. Adapun analisis perhitungan nilai tambah produksi dapat dilihat pada Tabel 8 .

Tabel 8. Analisis Nilai Tambah UD. Mekar Sari Desa Siderejo Curup Tengah

\begin{tabular}{|c|c|c|c|}
\hline \multirow{2}{*}{\multicolumn{2}{|c|}{ Output,Input, harga }} & \multicolumn{2}{|c|}{ Nilai tambah } \\
\hline & & \multirow{2}{*}{$\begin{array}{r}\text { Crispy } \\
257,60\end{array}$} & \multirow{2}{*}{$\begin{array}{r}\text { Nugget/bln } \\
260,90\end{array}$} \\
\hline Hasil Produksi (output) (Kg) & A & & \\
\hline Bahan Baku (Input) (Kg) & B & 302,60 & 290,90 \\
\hline Tenaga Kerja (HOK/ Bln) & $\mathrm{C}$ & 120,00 & 120,00 \\
\hline Faktor Konversi & $\mathrm{D}=\mathrm{A} / \mathrm{B}$ & 0,85 & 0,90 \\
\hline Koefisien Tenaga kerja $(\mathrm{HOK} / \mathrm{Kg})$ & $E=C / B$ & 0,40 & 0,41 \\
\hline Harga Produk rata2 (Rp/Kg) & $\mathrm{F}$ & $70.000,00$ & 100.000 \\
\hline Upah rata2 (Rp/HOK) & G & $20.000,00$ & 20.000 \\
\hline \multicolumn{4}{|l|}{ Penerimaan Dan Keuntungan } \\
\hline Harga Bahan Baku (Rp/kg) & $\mathrm{H}$ & $20.000,00$ & $20.000,00$ \\
\hline Harga Input Lain $(\mathrm{Rp} / \mathrm{Kg})$ & I & $22.702,62$ & $24.551,59$ \\
\hline Nilai Output (RP/Kg) & $\mathrm{J}=\mathrm{D} * \mathrm{f}$ & $59.590,22$ & $89.687,18$ \\
\hline Nilai Tambah (Rp) & $\mathrm{K}=\mathrm{J}-\mathrm{H}-\mathrm{I}$ & $16.887,60$ & $45.135,59$ \\
\hline Rasio Nilai Tambah & $\mathrm{L} \%=\mathrm{K} / \mathrm{J} * 100 \%$ & $28,34 \%$ & $50,33 \%$ \\
\hline Pendapatan Tenaga Kerja (Rp) & $\mathrm{M}=\mathrm{E}^{*} \mathrm{G}$ & $7.931,26$ & $8.250,26$ \\
\hline Pangsa Tenaga Kerja & $\mathrm{N} \%=\mathrm{M} / \mathrm{K}^{*} 100 \%$ & $46,97 \%$ & $18,28 \%$ \\
\hline Keuntungan (Rp) & $\mathrm{O}=\mathrm{K}-\mathrm{M}$ & $8.956,34$ & $36.885,33$ \\
\hline Tingkat Keuntungan & $\mathrm{P} \%=\mathrm{O} / \mathrm{K}^{*} 100 \%$ & $53,03 \%$ & $81,72 \%$ \\
\hline \multicolumn{4}{|l|}{ Balas Jasa Pemilik Faktor Produksi } \\
\hline $\operatorname{Margin}(\mathrm{Rp})$ & $\mathrm{Q}=\mathrm{J}-\mathrm{H}$ & $39.590,22$ & $69.687,18$ \\
\hline Tenaga Kerja (HOK/ Bln) & $\mathrm{R} \%=\mathrm{M} / \mathrm{Q}^{*} 100 \%$ & $20,03 \%$ & $11,84 \%$ \\
\hline Modal ( Sumbangan Input Lain) & $\mathrm{S} \%=\mathrm{I} / \mathrm{Q}^{*} 100 \%$ & $57,34 \%$ & $35,23 \%$ \\
\hline KEUNTUNGAN \% & $\mathrm{T} \%=\mathrm{O} / \mathrm{Q}^{*} 100 \%$ & $23 \%$ & $53 \%$ \\
\hline
\end{tabular}

Sumber: Penelitian 24 Februari - 24 Maret 2012

Pada Tabel 8 dapat dilihat bahwa bahan baku yang diolah dalam produksi pengolahan crispy jamur adalah sebanyak $302.6 \mathrm{~kg}$ dengan harga rata-rata pembelian bahan baku sebesar Rp.20.000. Faktor konversi didasarkan pada besarnya perolehan output dari $1 \mathrm{Kg}$ bahan baku. Faktor konversi yang diperoleh adalah sebesar 0,85 untuk crispy artinya setiap $1 \mathrm{Kg}$ Jamur tiram Putih dapat menghasilkan $0,85 \mathrm{~kg}$ crispy. Untuk pengolahan nugget dalam satu bulan UD. Mekar sari menggunakan bahan baku sebanyak $290.9 \mathrm{~kg}$ jamur tiram putih segar, dengan rata-rata pembelian bahan baku seharga Rp.20.000. untuk pengolahan nugget faktor konversi yang diperoleh adalah 0,90. Artinya dalam satu $\mathrm{kg}$ jamur tiram putih segar dapat diolah menjadi $0,90 \mathrm{~kg}$ produk jadi dalam bentuk nugget. Hal tersebut menunjukan adanya pengurangan dari produksi jamur tiram. Jika jamur tiram dijual segar $1 \mathrm{~kg}$ dengan tingkat harga rata-rata 
Rp. 20.000, dengan pengolahan menjadi crispy dan nugget, jamur tiram $1 \mathrm{~kg}$ tersebut akan berkurang beratnya, jika menjadi crispy, jamur tiram satu $\mathrm{kg}$ tersebut menjadi 0,85 $\mathrm{kg}$ dan untuk pengolahan nugget jamur tiram putih satu $\mathrm{kg}$ akan menjadi nugget sebanyak $0,9 \mathrm{~kg}$. Faktor konversi pada pengolahan nugget dan crispy berbeda terjadi karena faktor konversi ditentukan oleh output. Semakin banyak jumlah output yang diperoleh dari input maka faktor konversi yang didapat akan semakin besar, hal ini akan berdampak pada nilai tambah karena semakin besar jumlah faktor konversi yang diperoleh maka akan semakin besar pula nilai tambah yang diciptakan dari suatu produk.

Produk jadi crispy dan nugget yang dihasilkan setelah dilakukan pengolahan yaitu sebanyak 257,6 kg dan 260,9 kg. Hasil tersebut lebih rendah jika dibandingkan dengan jumlah bahan baku yang digunakan sebelumnya. Hal tersebut dikarenakan terjadi penyusutan saaat pengolahan. Walaupun terjadi penurunan dari segi jumlah, akan tetapi untuk harga jual produk tersebut mengalami kenaikan jika dibandingkan dengan harga jual jamur segar yang dijual petani tersebut. Setelah dilakukan pengolahan produk tersebut, pengolahan Jamur tiram Putih segar menjadi crispy dan nugget terjadi percampuran bahan-bahan baku lainnya yang membuat produk menjadi crispy dan nugget lebih padat. Percampuran bahan-bahan penolong lainnya menjadikan jamur tiram putih segar yang digunakan sebagai bahan baku menjadi padat dan berisi, sehingga kandungan yang bercampur dalam produk jadi lebih kaya akan nutrisi dan protein.

\section{SIMPULAN DAN SARAN}

\section{Simpulan}

Berdasarkan hasil penelitian dan pembahasan yang telah dilakukan, dapat ditarik kesimpulan sebagai berikut:

1. Pendapatan usahatani jamur tiram di Kecamatan Curup Tengah yaitu sebesar Rp 20.087.181,78 per bulan dengan rata-rata pendapatan Rp. 3.347.863,63/bulan.

2. Usaha budidaya jamur tiram putih di Kecamatan Curup Tengah adalah layak untuk dikembangkan. Kesimpulan ini diperoleh berdasarkan kriteria kelayakan berikut:

a. Tingkat efisiensi usahatani jamur tiram di Kecamatan Curup Tengah rata-rata yaitu sebesar 1,88 per bulannya. Tingkat efisiensi ini menjelaskan bahwa usahatani jamur tiram putih di Kecamatan Curup Tengah efisien atau layak untuk dikembangkan.

b. Tingkat kelayakan BEP berdasarkan harga dan produksi, berdasarkan hasil penelitian yang dilakukan, tingkat BEP produksi rata-rata yaitu sebesar 10,80. Hal tersebut menjelaskan bahwa pengusaha usahatani jamur tiram harus menjual sebanyak 10,88 kg jamur tiram setiap bulannya agar tidak mengalami kerugian. Sedangkan untuk BEP harga 
didapat sebesar Rp 13,419 / kg. Hal tersebut menunjukan bahwa pelaku usahatani jamur tiram harus menjual produk jamur tiram dengan harga sama dengan Rp 13.703 / kg agar tidak mengalami kerugian.

3. Besarnya keuntungan bersih dari pengolahan produk jamur tiram menjadi crispy dan nugget yaitu sebesar Rp. 8.956,34,-/Kg dan Rp. 36.885,33,-/Kg pengolahan nugget lebih memberikan keuntungan jika dibandingkan dengan pengolahan crispy.

\section{Saran}

1. Produksi jamur tiram putih di Kecamatan Curup Tengah sebaiknya terus ditingkatkan, dengan skala usaha baglog diatas 1500. Akan efisien jika baglog membuat sendiri dan lebih efisien lagi jika melakukan inokulasi pembuatan bibit sendiri.

2. Proses pengolahan jamur tiram sebaiknya menciptakan hasil olahan yang tidak hanya menghasilkan crispy dan nugget, dari hasil penelitian yang telah dilakukan, pengolahan produk jamur tiram menjadi nugget lebih menguntungkan jika dibandingkan dengan pengolahan menjadi crispy.

3. Pemerintah Kecamatan Curup Tengah bekerjasama dengan Dinas Pertanian Kabupaten Rejang Lebong sebaiknya memberikan sosialisasi kepada masyarakat mengenai budidaya jamur tiram putih dan pengolahan jamur tiram putih agar semakin banyak masyarakat yang tertarik mengusahakannya.

4. Diperlukan bimbingan dan kerjasama dengan pihak pemerintah maupun swasta yang berkompeten dengan teknologi budidaya jamur tiram putih untuk menuju agribisnis jamur tiram putih.

\section{DAFTAR PUSTAKA}

Gittinger, J.P. 1986. Analisa Ekonomi Proyek-proyek Pertanian.Edisi kedua. Penerbit Universitas Indonesia.Jakarta

Gusfarina, Defira Suci.2007.Analisis Nilai Tambah dan Pemasaran Susu Sapi Perah di Kecamatan Selupu Rejang Kabupaten Lebong. Skripsi. Jurusan Sosial Ekonomi Pertanian Fakultas Pertanian, Universitas Bengkulu (tidak dipublikasikan)

Khairiah .2002. Analisis Nilai Tambah dan Pemasaran Nata de Coco di Kota Bengkulu. Jurusan Sosial Ekonomi Pertanian Universitas Bengkulu. (tidak dipublikasikan).

Pratiwi, Putri Sekar, 2010. Usaha jamur tiram Skala Rumah Tangga. Penebar Swadaya.Jakarta.

Soekartawi. 1995. Analisis Usahatani. UI-Press. Jakarta. 